\title{
BLOOD GLUCOSE LEVELS AND THE MICROSCOPIC STRUCTURE OF KIDNEY WISTAR RAT DIABETES MELLITUS UNDER THE EFFECT OF LAWSONIA INERMIS (LINN.) LEAVES ETHANOLIC EXTRACT
}

\author{
MUTIARA INDAH SARI ${ }^{1 *}$, MAYA ANJELIR ANTIKA², DWI RITA ANGGRAINI ${ }^{3}$
}

${ }^{1}$ Department of Biochemistry, Faculty of Medicine, University of Sumatera Utara Jl. Dr. Mansur Kampus USU Medan 20155, Indonesia. ${ }^{2}$ Department of Biomolecular Medicine, Faculty of Medicine, University of Sumatera Utara Jl. Dr. Mansur Kampus USU Medan 20155, Indonesia. ${ }^{3}$ Department of Anatomy, Faculty of Medicine, University of Sumatera Utara Jl. Dr. Mansur Kampus USU Medan 20155,

Indonesia. Email: muti_dr@yahoo.com

Received: 06 November 2017, Revised and Accepted: 08 January 2018

ABSTRACT

Objective: Lawsonia inermis (Linn.) leaves are one of the alternative medicines to treat diabetes mellitus in Indonesia. We investigated the blood glucose level (BGL) of the L. inermis (Linn.) leaves ethanolic extract (LLEE) leaves and evaluated the histopathological alterations in diabetic rats.

Methods: This study was an experimental study with posttest - only control group design. Alloxan (120 mg/kg, intraperitoneally)-induced diabetic rats. 35 of Wistar rats (Rattus norvegicus) were divided randomly into five groups, i.e. K: Normal control, P1: Diabetic control, and P2, P3, and P4 (200 mg/kg body weight [BW], $400 \mathrm{mg} / \mathrm{kg} \mathrm{BW,} \mathrm{and} 600 \mathrm{mg} / \mathrm{kg}$ BW of LLEE, orally) for 28 days. At the end of the treatment, the rats were sacrificed to obtain the kidney for histopathological evaluation using hematoxylin and eosin technique. BGLs were conducted using a glucose meter (GlucoDR).

Results: One-way ANOVA test showed that dose $400 \mathrm{mg} / \mathrm{kg}$ BW of the LLEE was related to BGL of alloxan-induced diabetic rats (p=0.000). The histopathological of kidney showed glomerular inflammation (GI), epithelial membrane lining degeneration, vascular congestion, and interstitial tubule hemorrhage at diabetic control (P1). Meanwhile, treated with $600 \mathrm{mg} / \mathrm{kg}$ BW of LLEE (P4) showed increase cellular regeneration as normal architecture of the kidney.

Conclusion: The LLEE at dose $400 \mathrm{mg} / \mathrm{kg}$ BW effective decreased BGL and was able to restore the kidney destruction of alloxan-induced diabetic rats at dose $600 \mathrm{mg} / \mathrm{kg} \mathrm{BW}$.

Keywords: Lawsonia inermis (Linn.), Ethanolic extract, Blood glucose levels, Kidney, Diabetic rats.

(C) 2018 The Authors. Published by Innovare Academic Sciences Pvt Ltd. This is an open access article under the CC BY license (http://creativecommons. org/licenses/by/4. 0/) DOI: http://dx.doi.org/10.22159/ajpcr.2018.v11i4.23502

\section{INTRODUCTION}

The treatment by utilizing natural resources such as plants has become a tradition of people around the world. Utilization of these natural resources was done by taking the extracts of plants and made as a medicine. The alternative treatment that uses herbs extract of plants nowadays was also become an option instead of modern medicine [1]. The traditional medicines have more benefit, i.e. easy to find and cheap for the price. The traditional medicine from the plant that is less toxic and less severe side effect than chemical medicine. Since over the years, traditional medicine and traditional medical treatment have been existing in Indonesia [2]. One of the plants in Indonesia that is often used as a medicine is Henna/Lawsonia inermis (Linn.)/LL to treated diabetes mellitus (DM) [3].

Hyperglycemia is one of the symptoms of DM. Based on the data that International Diabetes Federation, estimated, 415 million people can be at risk become DM in the world. The number of DM patient keep increasing along last three decades and estimated in 2040 will be 642 million [4]. The destruction of the body such as pancreas, heart, kidney, and eyes can happen on the DM patient. This complication can cause the death [5]. The increasing of reactive oxygen species (ROS) has the role in the pathogenesis of the hyperglycemia complication should be treated with antioxidant therapy [6]. The LL contained flavonoid which was included in the largest phenol group in the perfiee tissue, also controlled the activity and or the expression of rate-limiting enzymes which involved in the carbohydrate metabolism [3]. When flavonoid was given in the routine ways for the long period, it could reduce the level of plasma glucose to $60 \%$ [7]. Flavonoids might be reducing glucose level by a mechanism independent from insulin secretion, for example, by the inhibition of endogenous glucose production or by the inhibition of intestinal glucose absorption [8]. The aim of this study was to obtained the effect of L. inermis (Linn.) leaves ethanolic extract (LLEE) with various doses on blood glucose levels (BGLs) and the histopathologic structure of rat kidney with alloxan induced.

\section{METHODS}

This study could be conducted after obtaining the approval from Faculty of Mathematics and Science ethic commission in University of Sumatera Utara (USU) with no of EC: 116/KEPH-FMIPA/2017. The study was conducted in Integrated Laboratory, Faculty of Medicine, Chemistry Laboratory of Faculty of Mathematics and Natural Sciences (FMIPA), and Biology Laboratory of FMIPA, USU.

Ethanol extraction of LL was done with maceration method that used ethanol solvent with ratio 1:10 (w/v). The dried LL was dissolved by 10 parts after that poured with 75 parts of ethanol $96 \%$ as the essence. Closed and left for 5 days and shielded from the light while stirring occasionally. After 5 days, the solution was filtered; the pulp was squeezed and washed with enough liquid essence to obtain 100 parts. The extract was obtained evaporated at a temperature of $50^{\circ} \mathrm{C}$ [9]. 35 of Wistar rats ( $R$. norvegicus), aged 2-3 months were divided randomly into five groups according to the Federer formula [10], with inclusion criteria: Male sex, age 2-3 months, body weight (BW) ranging from $150 \mathrm{~g}$ to $200 \mathrm{~g}$, and has not been used for other study. The rats were excluded 
if they died during the study. After adaptation for 1 week, Wistar rats were injected by alloxan at dose $120 \mathrm{mg} / \mathrm{kg}$ BW in the $0.1 \mathrm{M}$ citric buffer intraperitoneally [11]. The treatments were given as follows [8,12]:

1. Group K without any treatment.

2. Group P1 alloxan positive control $120 \mathrm{mg} / \mathrm{kg} \mathrm{BW}$.

3. Group P2 alloxan $120 \mathrm{mg} / \mathrm{kg} \mathrm{BW}$ and LLEE $200 \mathrm{mg} / \mathrm{kg} \mathrm{BW}$ orally.

4. Group P3 alloxan $120 \mathrm{mg} / \mathrm{kg} \mathrm{BW}$ and LLEE $400 \mathrm{mg} / \mathrm{kg} \mathrm{BW}$ orally.

5. Group P4 alloxan $120 \mathrm{mg} / \mathrm{kg} \mathrm{BW}$ and LLEE $600 \mathrm{mg} / \mathrm{kg}$ BW orally.

Treatment on the P2-P4 group was performed for 28 days starting from the BGLs $>250 \mathrm{mg} / \mathrm{dl}$ [13]. BGLs were the measurement by the glucose meter (GlucoDr ${ }^{\mathrm{TM}}$ ) using the glucose test strips. The blood specimen to measure the BGLs was taken from rats' tail [14]. The rats were sacrificed with light chloroform anesthesia on the 29 days. The result of sectioning tissue from kidney rats was the sampling of this study.

\section{Surgery of rats}

The surgical procedure performed through preparation, surgery, and sanitation by the routine procedure at Laboratory of Biology, FMIPA, USU. The stages of rat surgery in this study were killed by neck dislocation. The rats put on the surgery table by using pin needle. The surgical lower abdomen was started by using scissors, the kidney was taken and cleansed from the fat of kidney.

\section{Preparation stages}

Prepared organ pots that have been labeled according to the number of rats treatment. Organ pots were filled with $10 \%$ buffer formalin to store the organs. Prepared insulin syringe $1 \mathrm{ml}$. The syringe has been labeled and rinsed with heparin sodium as an anticoagulant to hold the blood. Surgical equipment for this study as follow: surgical scissor, tweezer, pin needle, petri dish, watch glass, surgical table, pins, and glass beaker.

\section{The stage of surgical}

Rats were killed by neck dislocation after light chloroform anesthesia. Rats were positioned on the surgical board using pins or pin needles. The surgery started in rat stomach using surgical scissors. The kidney organ was removed, washed using $0.9 \% \mathrm{NaCl}$, cleaned, and put in the pot containing of $10 \%$ formalin buffer.

\section{Sanitation stage}

Sanitation stage was done by inserting the rest of rat organ that was unused into a plastic bag which will be destroyed. The rest of the surgical work area was cleaned and the surgical equipment was washed.

\section{Preparation histology slides of kidney rats}

The preparation histology slides of kidney rats were done in at the Pathology Anatomic Laboratory of Faculty of Medicine, USU, with routine histology method. The stages of preparation are as follows.

\section{Fixation}

The kidney tissue of Wistar rats washed to remove the blood. The cutting of tissue was no more than $1 \mathrm{~cm} \mathrm{x} 1 \mathrm{~cm}$. The tissue fixation was immersed in $10 \%$ formalin for $24 \mathrm{~h}$.

\section{Dehydration}

The tissue was immersed until the entire tissue was submerged with alcohol. Dehydration performed using alcohols from low to high concentrations $(70 \%, 80 \%, 96 \%$, or absolute alcohol) for at least $12 \mathrm{~h}$.

\section{Clearing}

The tissue was inserted into xylol I solution for $30 \mathrm{~min}$, then inserted into the xylol II solution for $30 \mathrm{~min}$. The process was to be the clearing the tissue. With this process, the tissue will be clear and transparent.

\section{Embedding}

The three containers containing paraffin were prepared in the oven. The tissue was immersed in an existing oven paraffin container 1 for
$1 \mathrm{~h}$. Then, insert the tissue into container 2 for $1 \mathrm{~h}$. Next, insert the tissue to container 3 for $1 \mathrm{~h}$.

\section{Blocking}

The pieces of L-shaped iron (Leuckhart) were prepared for blocking. Two pieces of iron were arranged on a sheet of metal to form a space like a cube. The tissue which too is seen was put in the bottom of the cube to be flat. Paraffin was poured into a cube-shaped piece of iron, waited for up to $12 \mathrm{~h}$ until the paraffin freezes.

\section{Sectioning}

Paraffin blocks containing tissue were cut by a microtome. The piece of slices was not folded by microtome stomped so that the slide well formed. Created multiples slide. The slide is inserted into the tub temperature of $45-50^{\circ} \mathrm{C}$ for deparaffinization. Then, the glass object was smeared with albumin. Gradually, paste the specimen into the glass object. Let stand for $12 \mathrm{~h}$. Then, preparation was immersed with xylol I solution for 5 min to attract paraffin. Immerse with xylol II solution for $5 \mathrm{~min}$. Next, rehydrate with alcohol from high to low concentration so the tissue contained water can be stained. Dip the glass of objects which containing the tissue into absolute alcohol 2 times for $2 \mathrm{~min}$. Then, dip $90 \%$ alcohol as much as 2 times for $2 \mathrm{~min}$ in each. Continue on $80 \%$ alcohol for 2 times for $2 \mathrm{~min}$ in each. Last, alcohol concentration was $70 \%$ as much as 2 times for 2 min in each.

\section{Staining}

Object glass that contains tissue was inserted into hematoxylin solution for 5-10 minutes, rinsed with running water for 2-3 minutes, put into eosin solution, then rinsed over with running water. After that, dehydrated from low concentration alcohol to the high concentration alcohol In every 2 minutes in the order of $70 \%$ alcohol, $70 \%$ alcohol, $80 \%$ alcohol, $80 \%$ alcohol, $90 \%$ alcohol, and lastly two times into absolute alcohol. Then inserted the object glass contains tissue into xylol solution, respectively for 2 minutes: xylol I and xylol II Giving hematoxylin which was in the blue dye would stain the cytoplasm, nucleus, calcium due to the component that has alkaline. Meanwhile, eosin that was red dye would stain cytoplasm and connect the cells.

\section{Gluing (mounting)}

Dripped one drop of Canada Balsam on glass deck, close the glass objects which have the tissue, press repeatedly to make no bubble.

\section{Labeling}

Slides were given labeled.

\section{Data analysis}

The effect of LLEE to BGLs was obtained by processed and analyzed with as paired t-test using SPSS program version 16. The reading of preparation histopathology, after preparation, is ready to use observed under a microscope with $\times 400$ magnification at the Pathology Anatomic Laboratory of Faculty of Medicine, USU. The histopathological of kidney cell was analyzed by qualitatively descriptive such as the degeneration of cells, congesting or widening of blood vessels, inflammation, necrosis cells, and thickening of membrane basalis glomerulus. On the glomerulus (G), capsule Bowman (CB), proximal tubule (PT), and distal tubule (DT) analyzed of kidney appearance in each P1, P2, P3, and P4 groups compared

Table 1: The BGLs of rats before and after induced alloxan $120 \mathrm{mg} / \mathrm{kg} \mathrm{BW}$

\begin{tabular}{llll}
\hline Group & Before $(\mathbf{m g} / \mathbf{d l})$ & After $(\mathbf{m g} / \mathbf{d l})$ & $\mathbf{p}^{*}$ \\
\hline P1 & $152 \pm 17.08$ & $350 \pm 100.92$ & $0.000^{* *}$ \\
P2 & $119 \pm 14.57$ & $440 \pm 21.22$ & $0.000^{* *}$ \\
P3 & $112 \pm 14.50$ & $487 \pm 101.79$ & $0.000^{* *}$ \\
P4 & $105 \pm 13.21$ & $426 \pm 149.46$ & $0.000^{* *}$ \\
\hline *Paired t-test<0.05, ${ }^{* *}$ significance. BGLs: Blood glucose levels, BW: Body weight
\end{tabular}


to the normal control $(\mathrm{K})$. The records of the histological appearance were obtained by photomicrography using digital photomicrography microscope.

\section{RESULTS}

The BGLs of Wistar rats before and after alloxan induced at P1-P4 groups had shown at Table 1 .

At Table 1 can be seen, the BGLs before and after induced alloxan $120 \mathrm{mg} / \mathrm{kg}$ BW with a paired t-test on Groups P1-P4 showed the correlation $(\mathrm{p}<0.05)$.

Effect of LLEE on BGLs Wistar rat on the day $28^{\text {th }}$ had shown at Table 2 .

On Table 2, in the Groups P1, P3, and P4 of t-paired test analyzed showed decreasing BGLs between after alloxan induced compared to LLEE treated. The group receiving a dose of $400 \mathrm{mg} / \mathrm{kg} \mathrm{BW}$ had lower decrease (significantly $\mathrm{p}=0.003$ ).

The microscopic of the kidney tissue Wistar rats Group $\mathrm{K}$ can be seen in Fig. 1. The histopathological appearance of kidney in this group has not affected the hyperglycemia and also was not obtained the treatment LLEE.

The histopathology appearance of kidney on this Group (K) can be seen the normal structure of glomerulus (G) surrounded by the intact CB, DT, and PT without any inflammatory alterations.

In this study, the histopathological kidney hyperglycemia causes alloxan induced shows in Fig. 2.

In Fig. 2, microscopic groups of hyperglycemia rats after induced alloxan, $120 \mathrm{mg} / \mathrm{kg}$ BW shows the glomerular inflammation (GI),

Table 2: The BGLs of rats after induced alloxan and after LLEE treated on the day $28^{\text {th }}$

\begin{tabular}{llll}
\hline Groups & $\begin{array}{l}\text { BGLs after alloxan } \\
\text { induced (mg/dl) }\end{array}$ & $\begin{array}{l}\text { BGLs after LLEE } \\
\text { treated (mg/d) }\end{array}$ & $\mathbf{p}^{*}$ \\
\hline K & $160 \pm 78.03$ & $112 \pm 25.05$ & 0.394 \\
P1 & $350.33 \pm 100.92$ & $309 \pm 71.14$ & 0.687 \\
P2 & $440.33 \pm 21.22$ & $450 \pm 93.66$ & 0.884 \\
P3 & $487 \pm 101.79$ & $236 \pm 66.57$ & $0.003^{* *}$ \\
P4 & $426 \pm 149.46$ & $256 \pm 41.25$ & $0.052^{* *}$ \\
\hline
\end{tabular}

*Paired t-test $<0.05$, **significance. BGLs: Blood glucose levels, BW: Body weight, LLEE: Lawsonia inermis (Linn.) leaves ethanolic extract

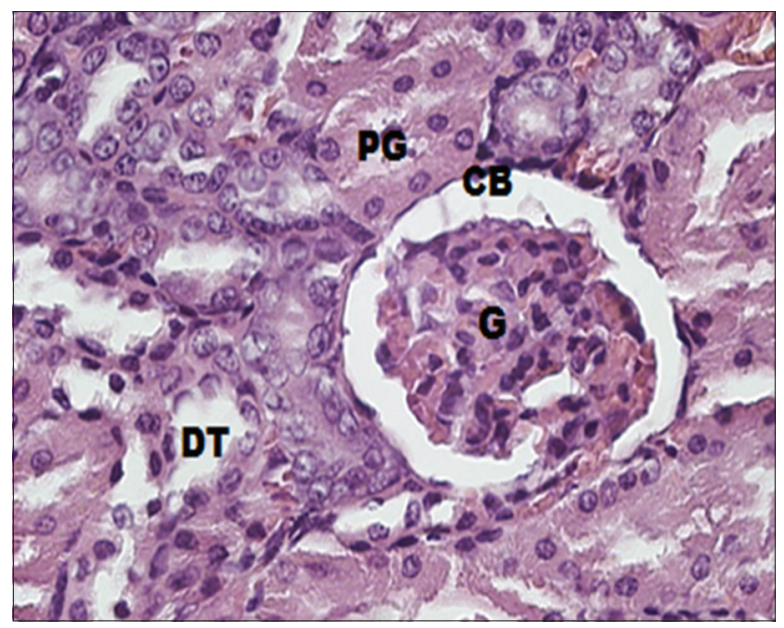

Fig. 1: The histopathological appearance of kidney in normal control (K) showed normal architecture, glomerulus, capsule Bowman intact, proximal tubule, and distal tubule (H and $\mathrm{E}, 400 \times$ ) epithelial membrane lining degeneration, vascular congestion (VC), and interstitial tubule hemorrhage.

In this study, the effect of natural antioxidants LLEE on the kidney tissue of Wistar rat alloxan-induced can be seen in Figs. 3-5

Fig. 5 The histopathological appearance of kidney in Group P4 showed increased cellular regeneration as a normal cellular architecture

Giving LLE $200 \mathrm{mg} / \mathrm{kg}$ BW on the diabetic Wistar rats (P2) in Fig. 3 showed that there were GI, VC, and interstitial tubule hemorrhage. Microscopically, the damaging of cells that occurred in Wistar rats Group P2 almost same with the damaging of cell in the Group P1. In this study, LLEE with dose $200 \mathrm{mg} / \mathrm{kg}$ BW could not prevent or fix the damage of kidney cell on the hyperglycemia induced by alloxan.

Descriptive microscopic of the P3 group (LLEE $400 \mathrm{mg} / \mathrm{kg} \mathrm{BW}$ ) could be seen in Fig. 4. Histopathology of cell kidney showed that it was still seen glomerular (G) inflammation, but VC was less than Group P2. Compared with the image of histopathology Group P4 (treated with LLEE at $600 \mathrm{mg} / \mathrm{kg} \mathrm{BW}$ ) that was shown in Fig. 5. The microscopic of cell in this group showed that normal cell of kidney with increased cellular regeneration.

\section{DISCUSSION}

In this study, BGLs before and after induced alloxan $120 \mathrm{mg} / \mathrm{kg}$ BW with paired t-test on all group (P1-P4) showed the correlation $(p<0.05)$. Alloxan compounds were one of the most toxic diabetogenic substances, especially to pancreatic beta cells, and when given to experimental animals such as rats can cause diabetic to the rats [11]. The alloxan toxicity mechanism begun with the entry of alloxan into the pancreatic $\beta$ cells and the retrieval rate will determine the alloxan diabetogenic properties.

In this study, there was an association between the extracted ethanol of $L$. inermis (Linn.) leaves with the decreasing of BGLs in the group of an experimental rat with $\mathrm{p}<0.05$ (Table 2). L. inermis Linn. is an one of the 40 types of plants used as medicines and listed in the list of drugs "Ebers Papyrus" written in 1550 BC. Based on phytochemical screening, the leaves of L. inermis (Linn.) contained phenolic compounds glycosylation proteins (coumarins, flavonoids, alkaloids, and tannins derivatives) [15]. A study by Fitrianda et al. showed that the effect of flavonoids-containing herbs could decrease BGLs alloxan-induced diabetic Wistar rats [16]. Flavonoids can inhibit polyol pathways through inhibition of aldose reductase enzyme. The alkaloid is an

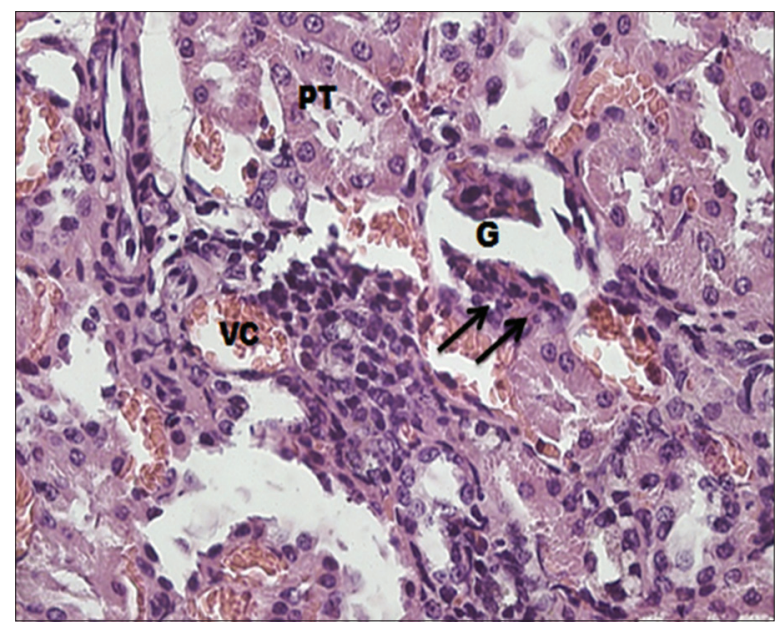

Fig. 2: The histopathological appearance of kidney in diabetic control (P1) showed: Glomerular inflammation, epithelial membrane lining degeneration (black arrow), vascular congestion, interstitial tubule hemorrhage ( $H$ and $E, 400 x$ ) 


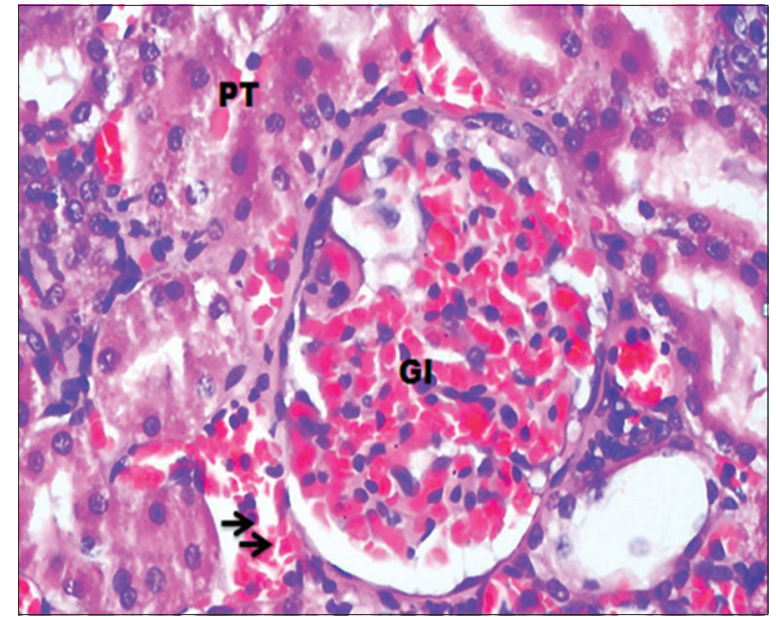

Fig. 3: The histopathological appearance of kidney in Group P2 showed glomerular inflammation, vascular congestion, interstitial tubule hemorrhage ( $\mathrm{H}$ and $\mathrm{E}, 400 \times$ )

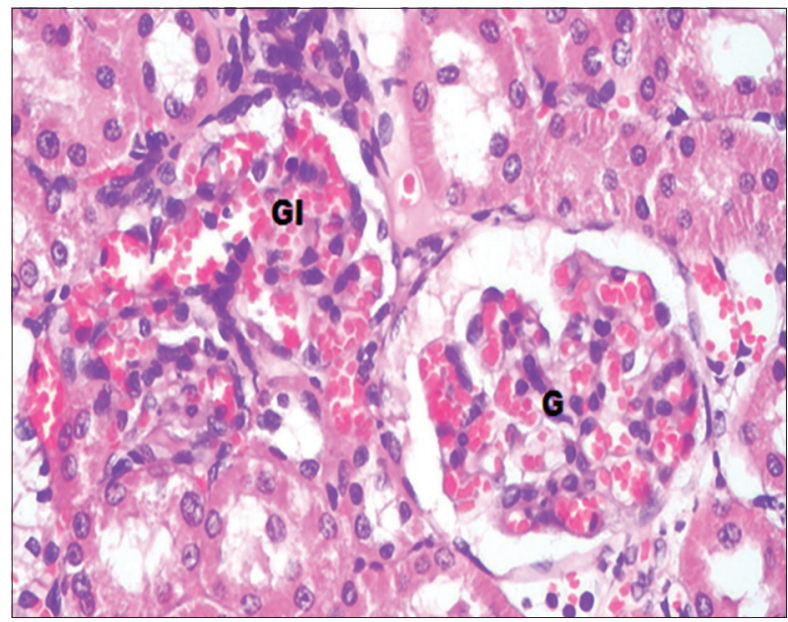

Fig. 4: The histopathological appearance of kidney in Group P3 showed glomerular inflammation, decrease of vascular congestion (H and E, 400x)

antioxidant that can reduce free radicals due to giving alloxan. Tannin has hypoglycemic activity by increasing glycogenesis process [15].

The image of kidney histopathology on this Group (K) can be seen normal structure, but after alloxan induced at $120 \mathrm{mg} / \mathrm{kg}$ BW shows the GI, epithelial membrane lining degeneration, $\mathrm{VC}$, and interstitial tubule hemorrhage.

The kidney is the organ which has the role to keep the balancing of liquid and electrolyte also to control the blood pressure. The functional unit of the kidney is called nephron. Structural nephron contains glomerulus, capsule, and tubules. The condition of hyperglycemia can cause nephron damage. Diabetes control and complications trial and UK Prospective Diabetes Study show that hyperglycemia is the first cause of tissue damaging [17].

The study was similar to the previous study by Mohsen et al. showed that the destruction of the kidney. The study stated the proof of injection of alloxan $120 \mathrm{mg} / \mathrm{kg}$ BW subcutaneous after 1 week could cause the hyperglycemia condition in Wistar rats. After 8 weeks, decrypt histopathology from hyperglycemia rats' kidney showed the changing structure of vacuolar and interstitial from nephron tubules [18].

The width of complication on diabetes looks to be correlated with the concentration of blood glucose until over glucose that suspected as the main reason of the damaging of tissue. This phenomenon could be

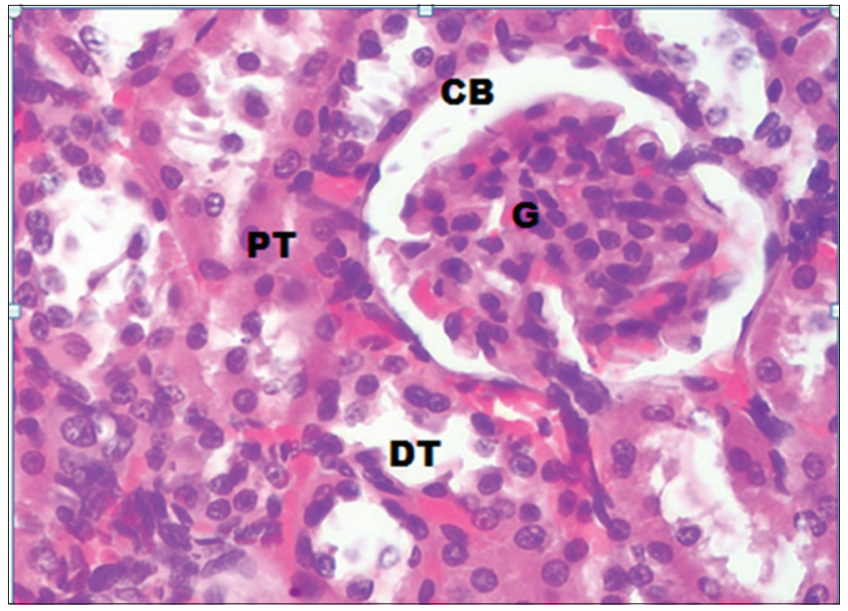

Fig. 5: The histopathological appearance of kidney in Group P4 showed increased cellular regeneration as a normal cellular architecture

caused by the ability of hyperglycemia in vivo ways into the modification oxidative in vary subtract. Oxidative stress plays a crucial role in the development of hyperglycemia, which generates ROS. The result of ROS in the tissue can cause the overproduction of nitric oxide that will create interference in the various organs $[19,20]$. In the normal condition, the increasing of ROS or oxidation could be solved by antioxidant. However, the condition of hyperglycemia in the unbalance happened between the level of oxidant and antioxidant. The additional antioxidant was needed from the outside body to respond this thing.

Effect of natural antioxidants LLEE on the kidney tissue of Wistar rat alloxan induced showed in Figs. 3-5.

The use of herbs medicine could not be separated from the possibility of side effects due to the secondary metabolism of toxin substance that contains the herbs. This study was about the toxicity of LL that had been conducted before. In this study, there was no toxicity effect of the LL on tissue [12]. Dembinska-kiec et al. showed that flavonoids work as antioxidants by increasing the activity of SOD [21]. Flavonoids work as the radical scavenger, for oxygen singlet radicals and lipid peroxidation. Flavonoids suppressed the action peroxidase, thereby, inhibited the form of ROS by neutrophils. Flavonoids also inhibit the form of ROS by suppressing the action of enzymes production [22-24]. As a potential antioxidant, flavonoids tied the metals and stabilized the metals till the metals could not catalyze the reaction of free radical. Flavonoids dampen the reactivity of free radicals. Thus, it led to the molecule to be more stable. Flavonoids also led to donate ions hydrogen or electrons to the anions superoxidant until protecting lipoproteins, proteins, and DNA from oxidation [25]. The damaging of kidney cells organs due to hyperglycemia could be reversible. Repairing the function of the pancreas will create BGLs, the damaging of the kidney can overcome. The cells of kidney cells could repair and form the new cells.

\section{CONCLUSION}

Based on the results of this study that the LLEE dose $400 \mathrm{mg} / \mathrm{kg} \mathrm{BW}$ effective decreased BGL and evaluated histopathological was able to restore the kidney destruction of alloxan-induced diabetic rats at LLEE $600 \mathrm{mg} / \mathrm{kg} \mathrm{BW}$.

\section{CONFLICTS OF INTERESTS}

The authors declare: There was no conflict of interest in this study.

\section{AUTHORS' CONTRIBUTION}

Mutiara Indah Sari: literature research, designing the methodology of research, examining the blood specimen and reading the result of blood 
specimen, analyzing the statistic data and writing the manuscript. Maya Anjelir Antika: collecting and preparing the sample, examining the blood specimen and reading the result of blood specimen, making the herbs, analyzing the statistic data. Dwi Rita Anggraini: literature research, analyzing the result of histopatology, analyzing the statistic data.

\section{REFERENCES}

1. Bailey CJ, Day C. Traditional plant medicines as treatments for diabetes. Diabetes Care 1998;12:553-64.

2. Muhtadi A, Irenka Y, Ayu WC, Hendriani R, Zuhrotun A. Hypoglycemic Activity of 10 Medicinal Plants Extract in Glucose-induced Mice. II-Indonesian Conference on Clinical Pharmacy. Available from: http://www.creativecommons.org/licenses/by/4.0/. [Last cited on 2017 Oct 25].

3. Prakash O, Kumar R, Srivastava R, Tripathi P, Mishra S, Ajeet. Plants explored with anti-diabetic properties: A review. Am J Pharmacol Sci 2015;3:55-66.

4. International Diabetes Federation. Diabetes Atlas. $7^{\text {th }}$ ed. Brussels, Belgium: International Diabetes Federation; 2015.

5. Acta American Diabetes Association. Diagnosis and classification of diabetes mellitus. Diabetes Care 2012;35:S64-71.

6. Mohora M, Greabu M, Muscurel C, Duta C, Totan A. The sources and the targets of oxidation stress in the etiology of diabetic complication. Rom J Biophy 2007;17:63-84.

7. Brahmacari G. Bio-flavonoid with promising anti-dabetic potentials: A critical survey. Opportunity, challenge and scope of natural products in medicinal. Chemistry 2011;2:187-212.

8. Abhinayani G, Kishore RN, Benazir F, Agarwal P. Anti-diabetic activity of Epipremnum aureum.L in normal and alloxan-induced diabetic rats. Asian J Pharm Clin Res 2016:9:89-92.

9. Syamsudin I, Winarno H. The effect of inai (Lawsonia inermis) leaves extract on blood glucose level: An experimental study. Res J Pharm 2008;2:20-3

10. Federer W. Statistics and Society: Data Collection and Interpretation. $2^{\text {nd }}$ ed. New York: Marcel Dekker; 1991.

11. Chougale AD, Panaskar SN, Gurao PM, Arvindeka AU. Optimization of Alloxan Dose is Essential to Induce Stable Diabetes for Prolong Period; 2007. Available from: http://www.sciarlet.net/ fulltext/?doi=ajb2007.402.408. [Last cited on 2016 Aug 10].
12. Chikaraddy A, Maniyar Y, Mannapur B. Hypoglycemic activity of ethanolic extract of Lawsonia inermis Linn. (Henna) in alloxan-induced diabetic albino rats. Int J Pharm Biol Sci 2012;2:287-92.

13. Nugroho AE. Animal models of diabetes mellitus: Pathology and mechanism of some diabetogenic biodiversitas. J Biol Divers 2006;7:378-82

14. Rajaram K. Antioxidant and antidiabetic activity of Tectona grandis Linn. In alloxan Induced albino rats. Asian J Pharm Clin Res 2013;3:1974-77.

15. Ben HA, Trigui M, Culioli G, Blache Y, Jaoua S. Antioxidant constituents from Lawsonia inermis leaves Isolation, structure elucidation and antioxidative capacity. Food Chem 2011;125:193-200.

16. Fitrianda E, Sukandar EY, Elfahmi E, Adnyana IK. Antidiabetic activity of extract, fractions, and asiaticoside compound isolated from Centella asiatica Linn. Leaves in alloxan-induced diabetic mice. Asian J Pharm Clin Res 2017;10:268-72.

17. Fioretto P, Mauer M. Histopathology of diabetic nephropathy. Semin Nephrol 2007;27:195-207.

18. Mohsen P, Ebrahim N, Hamid S. Early renal histological changes in alloxan-induced diabetic rats. Int J Mol Cell Med 2014;3:11-5.

19. Yuvraj SS, Purnima A, Rajendran R. Evaluation of antidiabetic, hypolipidemic and antioxidant activity of polyherbal formulation in streptozotocin-nicotinamide induced diabetes in rats. Int J Pharm Pharm Sci 2017;910;105-10

20. Moussa SA. Oxidative stress in diabetes mellitus. Rom J Biophys 2008;18:225-36

21. Dembinska-kiec A, Mykkanen D, Kiec-Wilk B, Mykkanen H. Antioxidant phytochemicals againts Type-2 diabete. $\mathrm{Br} \mathrm{J}$ Nutr 2008;99:109-17.

22. Zhang M, Cao J, Chen X, Wang Q. Flavonoid contents and free radical scavenging activity of extract from leaves, stem, rachis, and roots of Dryopteris erithrosora. Iran J Pharm Res 2011;11:991-7.

23. Kirchner T, Hermann E, Möller S, Klinger M, Solbach M, Laskay T, et al. Flavonoids and 5-aminosalicylic acid inhibit the formation of neutrophil extracellular. Traps Mediators Inflamm 2013;14. DOI. org $/ 10.1155 / 2013 / 710239$

24. Elshamy AI, Gendy AE, Farrag AR, Nassar MI. Antidiabetic and antioxidant activities of phenolic extracts of Conyza dioscoridis 1 . shoots. Int J Pharm Pharm Sci 2015;7:65-72.

25. Norshazila S, Zahir S, Suleiman M, Aisyah MR, Rahim K. Antioxidant levels activities of the selected seed of Malaysian tropical fruits. Mal J Nutr 2010;16:149-59. 